\title{
FIRMALARIN SERMAYE YAPISI KARARLARI ÜZERİNDE ETKİLİ OLAN MÍKRO DÜZEYLİ FAKTÖRLER: BİST TEKSTİL VE DERİ ENDEKSİNDEKİ FİRMALAR ÜZERİNE BİR ARAŞTIRMA
}

\author{
Micro Level Factors That Are Effective \\ On The Capital Structure Decisions Of Companies: \\ A Research On Companies In BIST Textile And \\ Leather Index
}

Eda DİGİL*

Geliş: 18.07.2019/Kabul: 29.11.2019

DOI: $10.33399 /$ biibfad.593496

Öz

Bu çalışmanın amacı BİST Tekstil ve Deri endeksinde yer alan firmaların sermaye yapısı üzerinde etkili olan mikro düzeyli faktörlerin tespit edilmesidir. Bu amaçla ilk olarak endekste yer alan firmaların 2011-2018 yıllarına ait bilanço ve gelir tablosu verileri kullanılarak çalışmada kullanılacak finansal oranlar hesaplanmış ve daha sonra ise panel veri analizi yapılmıştır. Panel veri analizinde sermaye yapısı ile ilgili finansal oranlar bağımlı değişken olarak kullanılırken karlılık, likidite ve varlık kullanım etkinliği ile ilgili finansal oranları ise bağımsız değişken olarak kullanılmıştır. Çalışmada sermaye yapısı ile ilgili dört farklı değişken ile dört farklı model oluşturularak analiz yapılmıştır. Yapılan analiz sonucunda kaldıraç oranı ile faiz vergi öncesi kar oranı, brüt kar oranı, çalışma sermayesi oranı, stokların ortalama tüketim süresi arasında; kısa vadeli borç oranı ile net kar oranı, cari oran, dönen varlık oranı ve uzun vadeli borç devir hızı arasında; uzun vadeli borç oranı ile faiz vergi öncesi kar, uzun vadeli borç devir hızı, toplam

* Doktora Öğrencisi, Gaziantep Üniversitesi Sosyal Bilimler Enstitüsü İşletme Ana Bilim Dalı, dizgileda@gmail.com , ORCID: https:/ / orcid.org/0000-0001-9164-2161 
borç devir hızı ve brüt kar oranı arasında; öz kaynak oranı ile aktif karlılık oranı, faiz vergi öncesi kar oranı, brüt kar oranı, dönen varlık oranı, çalışma sermayesi oranı ve uzun vadeli borç devir hızı arasında anlamlı ilişki olduğu tespit edilmiştir.

Anahtar Kelimeler: Sermaye yapısı, Panel Veri Analizi, Likidite ve Karlılık Oranları

Jel Kodlari: C33; G32; E2

\begin{abstract}
The aim of this study is to determine the micro level factors that affect the capital structure of firms in BIST Textile and Leather Index. For this purpose, firstly the financial ratios to be used in the study were calculated by using the balance sheet and income statement data of the companies in the index for the years 2011-2018 and then panel data analysis was performed. In the panel data analysis, financial ratios related to capital structure were used as dependent variables, while financial ratios related to profitability, liquidity and asset utilization effectiveness were used as independent variables. In this study, four different models and four different models related to the capital structure were created and analyzed. As a result of the analysis, the leverage ratio and the profit before interest tax rate, gross profit rate, working capital ratio, average consumption time of stocks; between the short-term debt ratio and the net profit ratio, current ratio, current asset ratio and long-term debt turnover rate; between long-term debt ratio and interest before tax, long-term debt turnover rate, total debt turnover rate and gross profit rate; It was found that there is a significant relationship between equity ratio, asset rate, profit before interest tax, gross profit rate, current asset rate, working capital rate and long term debt turnover rate.
\end{abstract}

Keywords: Capital Structure, Panel Data Analysis, Liquidity and Profitability Ratios

Jel Codes: C33; G32; E22

\title{
1. Giriş
}

Sermaye yapısı kararları firmaların temel karar alanlarından biridir. Bu kararların firmanın sermaye yapısı ve piyasa değeri üzerinde doğrudan etkilidir. Sermaye yapısı kısaca firmanın kaynak yapısı olarak ifade edilmektedir. Bu kaynak yapısı firmaların bilançolarının pasif tarafından oluşmaktadır. Sermaye yapısı firmaların faaliyetlerine devam edebilmeleri ve yeni yatırımlar yapabilmelerine imkân sağlayan finansman yapısı olarak da ifade edilebilmektedir. Bu bakımdan 
firmaların sürekliliği ve yaşamlarının devamı, değişen çevre şartlarına uyum ve rekabet avantajı sağlamada verilecek sermaye yapısı kararları son derece önem arz etmektedir (Burucu ve Öndeş, 2016:202; Ayaydın vd.,2017:44). Bu sebeple sermaye yapısı üzerinde etkili faktörlerin tespit edilmesi oldukça önemli bir konu haline gelmiş ve konu hakkında yapılan çalışmaların sayısında büyük bir artış olmuştur.

Özellikle Modigliani-Millerin 1958 yılında yayınladı̆̆ı makalesinden sonra konu ile ilgili olarak yapılan ampirik çalışmalarda büyük bir artış olduğu görülmüştür. Modigliani - Miller çalışmasında sermaye yapısı kararlarının firma değeri üzerinde etkili olmadığını savunmaktadır. Makalesinde piyasalarda aksaklığa neden olacak hiçbir faktörün bulunmadığını yani bilgi asimetrisi ve temsil sorunun olmadığını kabul etmiştir (Chen ve Chen, 2011:10972; Ayaydın vd.,2017:44). Bundan sonra yapılan çalışmalarda ise bilgi asimetrisi ve temsil sorunu gibi piyasa aksaklıklarının sermaye yapısı üzerine etkisinin araştırıldı ğı birçok çalışma yapılmıştır.

Modigliani ve Miller'ın 1958' de geliştirdiği model ve bu modelden önce üzerinde konuşulan Net Gelir Yaklaşımı, Net Faaliyet Yaklaşımı ve Geleneksel Yaklaşım bir yana, özellikle son yıllarda ortaya atılan birçok teori içerisinde Ödünleşme Teorisi ve Finansman Hiyerarşisi Teorisinin de literatürde ayrı bir yeri bulunmaktadır. Modern sermaye yapısı teorilerinden sonra ise firmalar için en uygun sermayesi yapısının tespitine yönelik birçok teori geliştirilmiş olmasına rağmen firmalar için henüz en uygun sermaye yapısını belirleyecek sabit bir model geliştirilememiştir.

Firmaların sermaye yapıları bulundukları sektöre göre de farklılık gösterebilmektedir. Bazı firmaların aynı sektörde faaliyet gösterseler bile sermaye yapıları birbirinden farklı olabilmektedir (Brigham ve Houston, 1999:623; Brigham ve Ehrhardt, 2005:556; Erol vd.,2016:114).

Sermaye yapısı kararları ile ilgili yapılan çalışmalar incelendiğinde çalışmalarda daha çok firmalar için en uygun sermaye yapısının ne olduğu, bu yapı üzerinde hangi faktörlerin önemli olduğu ve firmanın piyasa değerini en çok artıran sermaye yapısı birleşimlerinin neler olduğu araştırılmıştır. Ancak firmalar için en uygun sermaye yapısı birleşiminin nasıl olması gerektiği konusuna henüz net bir cevap bulunamamıştır.

Bu çalışmanın amacı Borsa İstanbul Tekstil ve Deri Endeksinde hisseleri işlem gören firmaların sermaye yapısı kararları üzerinde etkili olan 
faktörlerin tespit edilmesidir. Bu amaçla endekste yer alan 11 firmanın 2011-2018 yıllarına ait yıllık bilanço ve gelir tablosu verileri kullanılarak panel veri analizi yapılmıştır.

\section{Literatür}

Linda vd., (1998) çalışmada Hollanda firmalarının sermaye yapısı kararlarını etkileyen faktörler araştırılmıştır. Çalışmada firmaların 19841995 yıllarına ait veri seti kullanılarak panel veri analizi yapılmıştır. Analizde iki model ve iki bağımlı değişken kullanılmıştır. Bunlar; toplam borç./ öz sermayenin defter değeri ve toplam borç/ öz sermayenin piyasa değeridir. Analizde piyasa değeri/ defter değeri, varlık yapısı, karlılık ve kazançlardaki dalgalanmalar ise bağımsız değişken olarak kullanılmıştır. Yapılan analiz sonucunda ise Hollanda firmalarının sermaye yapılarını açılamada finansman hiyerarşisi teorisinin geçerli olduğu tespit edilmiştir. Firmaların iç finansmanı dış finansmana kıyasla daha çok tercih ettikleri ifade edilmiştir.

Graham vd., (2004) çalışmada Avrupa' daki Kobilerin sermaye yap1larına etki eden faktörler araştırılmıştır. Bu amaç doğrultusunda 8 Avrupa ülkesinden 500 Kobi' nin yatay kesit verisi kullanılarak regresyon analiz yapılmıştır. Analizde kısa vadeli borç oranı ve uzun vadeli borç oranı bağımlı değişken olarak kullanılmıştır. Bağımsız değişken olarak da karlılık, büyüme varlık yapısı ve firma yaşı kullanılmıştır. Yapılan analiz sonucunda ise bağımlı ve bağımsız değişkenler arasında anlamlı ilişkiler tespit edilmiştir.

Fıratoğlu (2005) çalışmasında kriz dönemlerinde firmaların sermaye yapısı kararları üzerinde etkili olan faktörleri araştırmıştır. Çalışmada İMKB' de işlem gören 196 adet mali olamayan şirketin mali tablo verilerini kullanarak panel veri analizi yapmıştır. Yaptığı analizde ise sırasıyla borçluluk oranı, karlılık, varlık yapısı, faaliyet riski, vergi faktörü, firma büyüklüğü, TobinQ oranı değişkenlerini kullanmıştır. Analiz sonucunda karlılık ve sermaye yapısı arasında negatif yönlü, büyüme fırsatları ile borçlanma arasında ise incelenen bütün dönemlerde pozitif bir ilişki olduğu tespit edilmiştir.

Albayrak ve Akbulut (2008) firmaların sermaye yapısı üzerinde etkili olan faktörleri karar ağacı algoritmalarından CRT yöntemini kullanarak 
araştırmışlardır. Çalışmada İMKB Sanayi ve hizmet sektöründe faaliyet gösteren firmaların verileri kullanılarak analiz yapılmıştır. Bu doğrultuda 38 farklı finansal gösterge kullanarak sermaye yapısı üzerinde etkili olan faktörleri tespit etmeye çalışmışlardır. Analiz sonucunda sermaye yapısı üzerinde etkili olan en önemli göstergelerin likidite, varlık kullanım etkinliği ve firma risk göstergeleri olduğunu tespit etmişlerdir.

Demirhan (2009) tarafından yapılan çalışmada firma düzeyli faktörlerin sermaye yapısı üzerindeki etkisi araştırılmıştır. Çalışmada İMKB Hizmet sektöründe yer alan firmaların 2003-2006 yıllarına ait veri seti kullanılarak çoklu regresyon analizi yapılmıştır. Analizde sermaye yapısı ile ilgili finansal oranlar bağımlı değişken; varlık yapısı oranı, karlılık oranları, firma büyüklüğü göstergeleri, firma riski göstergeleri, vergi oranı, borç dışı vergi kalkanı, borçlanma maliyeti, firma likiditesi ise bağımsız değişken olarak belirlenmiştir analiz sonucunda firmaların sermaye yapılarının finansal hiyerarşi teorisine uygun olduğu tespit edilmiştir.

Güler (2010) tarafından yapılan çalışmada KOBI'lerin sermaye yapıları üzerinde etkili olan faktörlerin neler olduğu araştırılmıştır. Bu doğrultuda ilgili firmaların 1996-2006 yıllarına ait veri setleri kullanılarak panel koentegrosyon analizi yapılmıştır. Analiz sonucunda kaldıraç oranı ve kısa vadeli borç oranının bağımsız değişken olarak yer aldığı modellerde etkili olan değişkenlerin likidite, borç dışı vergi kalkanı ve işletme büyüklüğü değişkenlerinin etkili olduğu tespit edilmiştir. Kobilerin sermaye yapısı teorilerinden finansal hiyerarşi teorisine uygun olarak hareket ettikleri ifade edilmiştir.

Uysal (2010) tarafından yapılan tez çalışmasında sermaye yapısı üzerinde etkili olan faktörler sektörel olarak araştırılmıştır. Çalışmada Türkiye Cumhuriyet Merkez Bankasının 1996-2008 yıllarına ait sektör bilançolarını kullanarak panel veri analizi yapılmıştır. Analizde sermaye yapısı ile ilgili finansal oranlar bağımlı değişken; iflas riski, borç dışı vergi kalkanı, varlık yapısı, firma büyüklüğü, büyüme fırsatları ve firma karlılığı ise bağımsız değişken olarak belirlenmiştir. Analiz sonucunda ise borç dışı vergi kalkanı ile borçlanma arasında negatif bir ilişki olduğu buna karşın iflas riski ile borçlanma arasında herhangi ilişki bulunmadığı ifade edilmiştir. Ayrıca çalışma sonuçların ödünleşme kuramını desteklediği belirtilmiştir. 
Doğan (2013) tarafından yapılan çalışmada sermaye yapısı kararları ve karlılık arasında herhangi bir ilişki olup olmadığını araştırılmıştır. Bu doğrultuda hisseleri borsada işlem gören sigorta firmalarının 20052011 yıllarına ait veri seti kullanılarak çoklu regresyon ve korelasyon analizi yapılmıştır Analiz sonucunda ise karlılık oranı ile sermaye yapısı arasında negatif bir ilişki bulunduğu tespit edilmiştir. Aktif büyüklüğü değişkeni ile karlılık arasında pozitif yönlü bir ilişki bulunduğu buna karşın firma yaşı değişkeni ile karlılık arasında ise negatif yönlü bir ilişki olduğu ifade edilmiştir.

Bozkurt (2014) tarafından yapılan çalışmada Borsa İstanbul' da Dengeleme teorisinin geçerli olup olmadığı araştırılmıştır. Bu amaçla hisseleri Borsa İstanbul' da işlem gören firmaların 2005-2010 yıllarına ait veri seti kullanarak panel veri analizi yapılmıştır. Çalışmada firmalar iflas riskine sahip olup olmamalarına göre iki gruba ayrılarak analiz yapılmıştır. Analiz sonucunda ise her iki grupta yer alan firmalar için borçlanma düzeyi ile firma değerleri arasında pozitif yönlü bir ilişki olduğunu tespit edilmiştir. Sonuç olarak borsa İstanbul' da işlem gören firmalar için dengeleme teorisinin geçerli olmadığı ifade edilmiştir.

Panda (2015), tarafından yapılan çalışmada Hindistan girişim sermayesi destekli gelişen firmaların sermaye yapısını etkileyen faktörlerin araştırılmıştır. Bu doğrultuda Hindistan'daki girişim sermayesi firmalarının finansman kararlarında etkili olan faktörleri tespit edilmesi amaçlanmıştır. Çalışmada girişim sermayesi firmalarının sermaye yapısını etkileyen maddi varlıklılar, karlılık, firma büyüklügüu, büyüme fırsatları ve oynaklık gibi çeşitli kavramlar dikkate alınarak bu firmalar için optimal sermaye yapısını belirlemeye yönelik kavramsal bir çerçeve çizilmiştir.

Coşkun vd., (2015) çalışmada sermaye yapısı kararları üzerinde etkili olan faktörlerin tespit edilmesi amaçlanmıştır. Bu doğrultuda Borsa İstanbul Sinai endeksinde yer alan firmaların 2003-2013 yıllarına ait veri seti kullanılarak yapay sinir ağları ile bir analiz yapılmıştır. Çalışmada kullanılan çıktı değişkenleri sermaye yapısı oranları; girdi değişkenlerini ise büyüme oranı, karlılık, borç dışı vergi kalkanı, nakit akış oranı, duran varlık/ toplam varlık, cari oran, finansal risk, net çalışma sermayesi, vergi oranı olarak belirlenmiştir. Analiz sonucunda cari oran, duran varlık/ toplam varlık ve net çalışma sermayesi değişkenlerinin 
sermaye yapısı üzerinde etkisi olan önemli değişkenler olduğu tespit edilmiştir.

Erol vd.,(2016), çalışmada borsada hisseleri işlem gören imalat sanayi firmalarının sermaye yapıları üzerinde Finansal Hiyerarşi Teorisinin geçerli olup olmadığını araştırılmıştır. Bu doğrultuda ilgili firmaların 2009-2013 yıllarına ait verilerini kullanarak panel veri analizi yapılmıştır. Analizde sermaye yapısı ile ilgili finansal oranları bağımlı değişken; borç dışı vergi kalkanı, karlılık, büyüme fırsatları, işletme büyüklüğü, likidite, varlık yapısı ve işletme riski değişkenlerini ise bağımsız değişken olarak belirlenmiştir. Çalışma sonucunda ise firmaların finansal hiyerarşi teorisine kısmen uygun davrandıkları tespit edilmiştir.

Burucu ve Öndeş, (2016) çalışmada Borsa İstanbul İmalat Sanayi firmalarının sermaye yapıları üzerinde Finansal hiyerarşi ve Dengeleme Teorisinin geçerli olup olmadığını araştırılmıştır. Bu doğrultuda 50 adet firmanın 1990-2014 yıllarına ait veri setini kullanılarak dinamik panel veri analizi yapılmıştır. Analizde sermaye yapısı oranı bağımlı değişken firma büyüklüğü, firma riski, büyüme fırsatları, varlık yapısı, karlılık, borç dışı vergi kalkanı, büyüme oranı, cari oran ise bağımsız değişken olarak belirlenmiştir. Çalışma sonucunda firma büyüklüğü, varlık yapısı, karlııı, cari oran ile kaldıraç oranı arasında negatif; büyüme ve büyüme fırsatları ile kaldıraç oranı arasında pozitif yönlü bir ilişki bulunduğunu tespit edilmiştir. Sonuç olarak da ilgili firmaların sermaye yapılarının finansal hiyerarşi teorisi ile uyumlu olduğunu ifade edilmiştir.

Karadeniz vd., (2016) çalışmada karlılık ve sermaye yapısı kararları arasındaki ilişki araştırılmıştır. Bu amaç doğrultusunda hisseleri Borsa İstanbul' da işlem gören Turizm firmalarının 2009-2015 dönemine ait çeyreklik veri seti kullanarak panel veri analizi yapılmıştır. Analizde net kar marjı, aktif kazanç gücü ve aktif karlılık oranı bağımlı değişken sermaye yapısı ile ilgili finansal oranlar ise bağımsız değişken olarak kullanılmıştır. Yapılan analiz sonucunda ise sermaye yapısı değişkenlerinden kısa vadeli kaldıraç oranı ile toplam kaldıraç oranı ile net kar marjı, aktif kazanç gücü ve aktif karlılığı arasında negatif bir ilişki bulunduğu belirlenmiştir. Buna karşın uzun vadeli kaldıraç oranı ile bütün karlılık değişkenleri arasında ise herhangi bir ilişki olmadığını bildirilmiştir. 
Ayaydın vd., (2017) çalışmada sermaye yapısı kararları üzerinde etkili olan faktörleri tespit edilmesi amaçlanmıştır. Bu doğrultuda hisseler Borsa İstanbul' da işlem gören Yüksek Teknoloji Firmalarının 2008-2015 yıllarına ait veri setini kullanarak panel veri analizi yapılmıştır. Analizde sermaye yapısı ile ilgili finansal oranlar bağımlı değişken; büyüme, büyüklük, borç dışı vergi kalkanı, varlık yapısı, karlılık, temettü dağıtımı, cari oran, ar-ge harcamaları, GSYİH, borsa kapitalizasyonu, enflasyon ve faiz oranlarını ise bağımsız değişken olarak belirlenmiştir. Analiz sonucunda Finansal Hiyerarşi ve Dengeleme Teorisinin geçerli olduğu tespit edilmiştir.

Alsu (2017) tarafından yapılan çalışmada karlılık ve sermaye yapısı arasındaki ilişki araştırılmıştır. Bu doğrultuda hisseleri borsa İstanbul'da işlem gören 2006-2015 yılları arasındaki verileri kullanılarak panel veri analizi yapılmıştır. Çalışmada karlılık oranı bağımlı değişken; öz kaynak oranı, uzun vadeli borç oranı ve yasal yedek oranını ise bağımsız değişken olarak kullanılmıştır. Analiz sonucunda öz kaynak oranı ve yasal yedek oranı ile karlılık oranı arasında anlamlı bir ilişki olduğu tespit edilmiştir. Buna karşın uzun vadeli borç oranı ile karlılık oranı arasında ise herhangi bir ilişkinin bulunmadığ ifade edilmiştir.

Saona vd., (2018) çalışamada sermaye yapısının belirleyicileri olarak grup bağlantısı ve sahiplik yapısı konsantrasyonu gelişmekte olan ülke ekonomileri bağlamında araştırılmış ve Santiago menkul kıymet borsasında hisseleri işlem gören firmaların 2002-2014 yıllarına ait veri seti kullanılarak panel veri analizi yapılmıştır. Analizde kaldıraç oranı bağımlı değişken olarak kullanılırken bağımsız değişkenler ise sırasıyla sahiplik yapısı, firma büyüklüğü, karlılık, varlık yapısı oranı, büyüme fırsatı, borç dışı vergi kalkanı olarak belirlenmiştir. Analiz sonucunda ise grup şirketlerinin yaptıkları işlerde daha çok iç sermaye piyasalarından yararlandıkları ve genellikle dış borçtan uzak durdukları tespit edilmiştir. Ancak bağlı şirketi olmayan firmalarda hissedarların hisse oranı arttıkça kaldıraç oranının arttı̆̆ı tespit edilmiştir. Buna ek olarak sahiplik yapısı ile kaldıraç oranı arasında negatif yönlü bir ilişkinin olduğu bildirilmiştir.

Akgül ve Sigalı (2018), çalışmada sermaye yapısı üzerinde etkili olan faktörlerin tespit edilmesi amaçlanmıştır. Bu amaçla hisseleri Borsa İstanbul Ulaştırma Endeksi' nde işlem gören firmaların 2002-2013 yıllarına 
ait veri setini kullanarak panel veri analizi yapılmıştır. Analizde uzun vadeli borç oranı ve kaldıraç oranını bağımlı; varlık yapısı, karlılık, likidite, firma büyüklüğü, kurumsal yönetim değişkenleri, oynaklık ve firma riski, GSYİH, Borç dışı vergi kalkanı gibi değişkenleri ise bağımsız değişken olarak kullanılmıştır. Yapılan analiz sonucunda ise varlık yapısı ve firma büyüklügüu ile uzun vadeli borç oranı arasında pozitif bir ilişki olduğu bu sonucun ise Dengeleme Teorisini desteklediği ifade edilmiştir. Buna ek olarak kurumsal yönetim uygulamaları ile ilgili değişkenlerinde sermaye yapısı kararları üzerinde etkili olduğunu belirtilmiştir.

Yousaf ve ftikhar (2018) çalışmada Pakistan'da otomotiv sektöründe faaliyet gösteren firmaların sermaye yapısı kararları üzerinde etkili olan faktörler araştırılmıştır. Çalışmada 21 otomotiv firmasının 2000-2011 yıllarına ait veri seti kullanılarak panel veri analizi yapılmıştır. Analizde kaldıraç oranı, kısa vadeli borç oranı, uzun vadeli borç oranı bağımlı değişken olarak karlılık büyüme yatırım fırsatları, kurumlar vergisi oranı, borç dışı vergi kalkanı, likidite, sermaye yoğunluğu ve firma büyüklüğü ise bağımsız değişken olarak belirlenmiştir. Yapılan analiz sonucunda likidite, büyüklük, karlılık, borç dışı vergi kalkanı, sermaye yoğunluğu ve etkin vergi oranı gibi sermaye yapısı değişkenlerinin Dengeleme Teorisi ile önemli ilişkiler gösterdiğini tespit edilmiştir. Ayrıca otomotiv firmalarının muhafazakâr bir anlayışa sahip olduğu ve hiçbir firmanın sermaye yapısında borç bulundurmak istemediklerini bildirilmiştir.

Jami ve Koloukhi (2018) çalışmada Tahran Menkul Kıymetler Borsasında hisseleri işlem gören firmaların sermaye yapılarının ve finansal performanslarının belirleyicilerinin tespit edilmesi amaçlanmıştır. Çalışmada 123 firmanın 2012-2017 yıllarına ait veri seti kullanılarak regresyon analizi yapılmıştır. Buna ek olarak dokuz farklı hipotez ve iki farklı model belirlenmiştir. İlk modelde kaldıraç oranı, kısa vadeli borç oranı, uzun vadeli borç oranı bağımlı değişken olarak kullanılırken bağımsız değişkenlerde sırasıyla firma büyüklüğü, firmanın yaşı, maddi duran varlık oranı, satışlar/ toplam varlıklar, sahiplik yapısı, toplam cari borç ve toplam cari varlıklardan kaynaklanan likidite, her bir hisse senedinin piyasa fiyatı, toplam aktif/ satışların standart sapması olarak belirlenmiştir. İkinci modelde ise cari ve bir önceki yılın faiz ve vergi öncesi karı bağımlı değişken olarak kullanılırken kaldıraç oranı, firma büyüklüğü ve reklam maliyetleri/ toplam satış ise bağımsız değişken 
olarak kullanılmıştır. Yapılan analiz sonucunda firma büyüklüğü, firmanın yaşı, satış hacmi ve toplam kazanç ile firmanın sermaye yapısı arasında anlamlı bir ilişki olduğu tespit edilmiştir. Diğer modelde ise firma büyüklügüu, finansal kaldıraç ve reklam maliyeti ile firma performansı arasında istatistiksel olarak anlamlı bir ilişki olduğu bildirilmiştir.

Belas vd., (2018) çalışmada KOBİ'lerin karakteristik özelliklerinin sermaye yapısı üzerine etkisinin araştırılmış ve bu doğrultuda Kobilerin sermaye yapısı belirleyicilerini tespit etmek amaçlanmıştır. Bu amaca paralel olarak dört belirleyici özellik kullanılmıştır. Bunlar; bölge, iş alanı, çalışan sayısı ve iş süresinin, yöneticinin bu konudaki kararları ve kararların sermaye yapısı kararları üzerine etkisi Çek Cumhuriyeti'ndeki Kobiler açısından incelenmiştir. Çalışmada analiz yöntemi olarak sıralı lojistik regresyon yöntemi kullanılmıştır. Bu doğrultuda beş farklı model belirlenmiştir. Yapılan analiz sonucunda çalışan sayısı ve firma büyüklügünün yabancı sermaye ve öz sermaye hacmi üzerinde etkili olduğunu tespit edilmiştir.. Ayrıca iş süresi ile yabancı sermaye arasında ise doğrusal bir ilişki bulunduğu bildirilmiştir.

\section{Uygulama}

\section{1. Çalışmanın Amacı, Kapsamı ve Yöntemi}

Bu çalışmanın amacı BİST Tekstil ve Deri Endeksinde yer alan firmaların sermaye yapılarına etki eden faktörlerin tespit edilmesidir. Bu amaçla hisseleri Borsa İstanbul Tekstil ve Deri endeksinde işlem gören firmaların 2011-2018 yıllarına ait yıllık bilanço ve gelir tablosu verileri kullanılarak panel veri analizi yapılmıştır. Çalışmada bu örneklemin seçilme nedeni daha önce tekstil ve deri endeksindeki firmaların sermaye yapısı üzerinde etkili olan faktörlerin tespitine yönelik herhangi bir çalışma yapılamamış olmasıdır. Çalışma kapsamındaki yer alan firmaların verileri Kamuyu Aydınlatma Platformu Web Sitesinden alınmıştır. Çalışma kapsamındaki firmaların listesi Tablo 1'de yer almaktadır. Analizde kullanılacak bağımlı ve bağımsız değişkenler ise Tablo 2' de gösterilmiştir. 
Tablo 1: Çalışmanın Örneklemini Oluşturan Firmaların Listesi

\begin{tabular}{|l|l|l|}
\hline \multicolumn{1}{|c|}{ No } & \multicolumn{1}{|c|}{ BİST Kodu } & \multicolumn{1}{c|}{ Firma Adı } \\
\hline 1 & ARSAN & Arsan Tekstil Ticaret ve Sanayi A.Ş \\
\hline 2 & BLCYT & Bilici Yatırım Sanayi ve Ticaret A.Ş \\
\hline 3 & BOSSA & Bossa Ticaret ve Sanayi İşletmeleri T A.Ş \\
\hline 4 & DAGI & Dagi Giyim Sanayi ve Ticaret A.Ş \\
\hline 5 & DERIM & Derimod Konfeksiyon Ayakkabı Deri Sanayi ve Ticaret A.Ş \\
\hline 6 & HATEK & Hatay Tekstil İşletmeleri A.Ş \\
\hline 7 & KORDS & Kordsa Teknik Tekstil A.Ş \\
\hline 8 & MNDRS & Menderes Tekstil Sanayi ve Ticaret A.Ş \\
\hline 9 & SKTAS & Söktaş Tekstil Sanayi ve Ticaret A.Ş \\
\hline 10 & YATAS & Yatak ve Yorgan Sanayi ve Ticaret A.Ş \\
\hline 11 & YUNSA & Yünsa Yünlü Sanayi ve Ticaret A.Ş \\
\hline
\end{tabular}

Tablo 2: Çalışmada Kullanılacak Bağımlı ve Bağımsız Değişkenler

\begin{tabular}{|c|c|c|}
\hline Kod & Değişken Adı & Açıklaması \\
\hline \multicolumn{3}{|c|}{ Sermaye Yapısı Değişkenleri (bağımlı değişkenler) } \\
\hline TBTA & Kaldıraç Oranı & Toplam borç/ toplam aktif \\
\hline KVBTA & Kısa vadeli borç oranı & Kisa vadeli yabancı kaynak/ toplam aktif \\
\hline UVBTA & Uzun vadeli borç oranı & Uzun vadeli borç/ toplam aktif \\
\hline OKTA & Özkaynak oranı & Öz kaynaklar/ toplam aktif \\
\hline \multicolumn{3}{|c|}{ Karlılık Oranları } \\
\hline NKTA & Aktif karlılık oranı & Net kar/ toplam aktif \\
\hline FVOK & Faiz vergi öncesi karlılık & Faiz vergi öncesi kar/toplam aktif \\
\hline FVOKOS & $\begin{array}{l}\text { Faiz vergi öncesi karın öz ser- } \\
\text { maye oranı }\end{array}$ & Faiz vergi öncesi kar/ öz sermaye \\
\hline NKNS & Net kar oranı & Net kar/ net satış \\
\hline BKNS & Brüt kar oranı & Brüt kar/ net satış \\
\hline FKNS & Faaliyet karı oranı & Faaliyet karı/ net satış \\
\hline \multicolumn{3}{|c|}{ Likidite Oranları } \\
\hline $\mathrm{CO}$ & Cari Oran & Dönen varlık/ kısa vadeli yabancı kaynak \\
\hline DVTA & Dönen varlık oranı & Dönen varlık/toplam aktif \\
\hline DVKVTA & Çalışma sermayesi oranı & $\begin{array}{l}\text { (Dönen varlıklar-kısa vadeli yabanc1 } \\
\text { kaynaklar)/ toplam aktif }\end{array}$ \\
\hline \multicolumn{3}{|c|}{ Varlık Kullanım Etkinliği Oranları } \\
\hline SDV & Stok orani1 & Stoklar/dönen varlıklar \\
\hline ALDH & Alacak devir hızı & Net satış/ ticari alacaklar \\
\hline AOTS & Alacakların Tahsil Süresi & 365/ Alacak devir hızı \\
\hline $\mathrm{SDH}$ & Stok devir hiz1 & Satılan ticari mallar maliyeti/ stoklar \\
\hline SOTS & Stok tüketim süresi & 365/ stok devir hizı \\
\hline UVBDH & Uzun vadeli bor devir hızı & Net satışlar/ uzun vadeli borçlar \\
\hline TBDH & Ticari borç devir hızı & Satışların maliyeti/toplam borç \\
\hline
\end{tabular}


Bu çalışmada hem yatay kesit hem de zaman serisi verileri bulunduğu için panel veri analizi yöntemi ile verilerin analiz edilmesine karar verilmiștir. Panel veri analizi kesitsel verilerin zaman serileri ile eș zamanlı olarak tek formda analiz edilmesidir (Tatoğlu, 2012: 4; Çoşkun ve Topalaoğlu, 2016: 6). Birçok panel veri uygulamasında çok fazla sayıda kesit verisine karşılık daha az sayıda zaman verisi olduğu görülmektedir (Ayaydın vd., 2017). Veri setinde her kesit için eşit sayıda zaman serisinin bulunduğu veriler dengeli panel veri olarak ifade edilirken her kesitin karşısında farklı miktarda zaman serisi bulunması durumunda ise bu veriler ise dengesiz panel veri olarak ifade edilmektedir (Ayaydın vd., 2017). Bu açılklamalar doğrultusunda çalışmada her kesit için eşit sayıda zaman serisi bulunması sebebiyle dengeli panel veri analizi yöntemi kullanılmıştır. Çalışmada firmaların sermaye yapısı kararları üzerinde etkili olan faktörlerin tespit edilmesi amacıyla dört farklı model oluşturulmuştur. Bunlar;

$$
\begin{aligned}
& \text { Model1: TBTA }=\beta_{1}+\beta_{2} \text { NKTA }_{i t}+\beta_{3} \text { FVOK }_{i t}+\beta_{4} B K N S_{i t}+ \\
& \beta_{5} \text { FKNS }_{i t}+\beta_{6} \text { DVKVTA }_{i t}+\beta_{7} \text { LOGSOTS }_{i t}+\beta_{8} \text { TBDH } H_{i t}+\varepsilon_{i t} \\
& \text { Model2: KVBTA }=\beta_{1}+\beta_{2} \text { NKNS }_{i t}+\beta_{3} \mathrm{CO}_{i t}+\beta_{4} \text { DVTA }_{i t}+ \\
& \beta_{5} S D H_{i t}+\beta_{6} A L D H_{i t}+\beta_{7} U V B D H S_{i t}+\varepsilon_{i t} \\
& \text { Model3: UVBTA }=\beta_{1}+\beta_{2} \text { FVOK }_{i t}+\beta_{3} U V B D H_{i t}+\beta_{4} \text { TBDH } H_{i t}+ \\
& \beta_{5} N K N S_{i t}+\beta_{6} B K N S S_{i t}+\varepsilon_{i t} \\
& \text { Model4: OKTA }=\beta_{1}+\beta_{2} \text { NKTA }_{i t}+\beta_{3} \text { FVOK }_{i t}+\beta_{4} \text { FVOKOS }_{i t}+ \\
& \beta_{5} \text { BKNS }_{i t}+\beta_{6} \text { FKNS }_{i t}+\beta_{7} \mathrm{CO}_{i t}+\beta_{8} D V T A_{i t}+\beta_{9} D V K V T A_{i t}+ \\
& \beta_{10} S D V_{i t}+\beta_{11} U V B D H_{i t}+\varepsilon_{i t}
\end{aligned}
$$

Çalışmada kullanılan değişkenlere ilişkin tanımlayıcı istatistikler Tablo 3' de yer almaktadir.

Tablo 3: Değişkenlere İlişkin Tanımlayıcı İstatistikler

\begin{tabular}{|l|c|c|c|c|}
\hline \multicolumn{1}{|c|}{ Değişkenler } & Ortalama & Maksimum & Minimum & Standart sapma \\
\hline TBTA & 0.54 & 0.89 & 0.07 & 0.20 \\
\hline KVBTA & 0.39 & 0.74 & 0.04 & 0.16 \\
\hline UVBTA & 0.15 & 0.52 & 0.003 & 0.12 \\
\hline OKTA & 0.44 & 0.92 & 0.10 & 0.2 \\
\hline
\end{tabular}




\begin{tabular}{|l|c|c|c|c|}
\hline NKTA & 0.02 & 0.16 & -0.18 & 0.058 \\
\hline FVOK & 0.03 & 0.47 & -0.24 & 0.08 \\
\hline FVOKOS & 0.22 & 2.11 & -1.66 & 0.60 \\
\hline NKNS & 0.038 & 0.88 & -0.32 & 0.14 \\
\hline BKNS & 0.23 & 1.00 & -0.01 & 0.145 \\
\hline FKNS & 0.088 & 0.66 & -0.38 & 0.11 \\
\hline CO & 1.60 & 10.03 & 0.56 & 1.41 \\
\hline DVTA & 0.51 & 0.99 & 0.22 & 0.20 \\
\hline DVKVTA & 0.12 & 0.56 & -0.20 & 0.15 \\
\hline SDV & 0.36 & 0.61 & 0.03 & 0.14 \\
\hline ALDH & 4.65 & 14.65 & 0.47 & 2.79 \\
\hline SDH & 4.55 & 25.12 & 1.21 & 5.05 \\
\hline STOS & 122.9 & 299 & 14 & 56 \\
\hline UVBDH & 12.37 & 128 & 0.54 & 18.58 \\
\hline TBDH & 1.14 & 4.13 & 0.42 & 0.56 \\
\hline
\end{tabular}

Değişkenler arasında korelasyon ilişki olup olmadığını tespit etmek amacıyla korelasyon analizi yapılmıştır. Korelasyon analizi değişkenler arasında herhangi bir ilişki olup olmadığını tespit etmek amacıyla yapılan ve iki değişken arasındaki ilişkinin yönü ve büyüklüğünü gösteren analizdir.

Modeldeki bağımsız değişkenler arasında yüksek korelasyon olması çoklu doğrusal bağlantı hatasına neden olabileceğinden sonuçlara güvenilmez. Bu doğrultuda yapılan korelasyon analizine ilişkin sonuçlar Tablo 4'de yer almaktadır.

Tablo 4: Korelasyon Tablosu

\begin{tabular}{|c|c|c|c|c|c|c|c|c|c|c|c|c|c|c|c|c|c|c|c|}
\hline & 鹿 & $\begin{array}{l}\mathbb{\Phi} \\
\stackrel{0}{0}\end{array}$ & 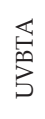 & $\begin{array}{l}\mathbb{v} \\
\text { o }\end{array}$ & $\vec{b}$ & 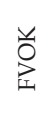 & $\begin{array}{l}\text { o } \\
0 \\
0 \\
\text { वे }\end{array}$ & $\begin{array}{l}\sum_{z}^{2} \\
\frac{1}{2}\end{array}$ & $\sum_{0}^{0}$ & $\sum^{\infty}$ & 8 & $\begin{array}{l}\mathbb{5} \\
\vec{b} \\
\vec{b}\end{array}$ & 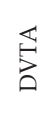 & 蒿 & की & : & कै & $\begin{array}{l}\frac{\pi}{1} \\
n_{3}^{0}\end{array}$ & $\begin{array}{l}\text { 志 } \\
\hat{\mathscr{A}}\end{array}$ \\
\hline 峞 & $r$ & & & & & & & & & & & & & & & & & & \\
\hline 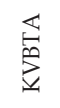 & $\begin{array}{l}\stackrel{\infty}{0} \\
0\end{array}$ & $\tau$ & & & & & & & & & & & & & & & & & \\
\hline $\begin{array}{l}\overleftrightarrow{.} \\
\text { 总 }\end{array}$ & 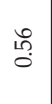 & $\begin{array}{l}\text { : } \\
\end{array}$ & $r$ & & & & & & & & & & & & & & & & \\
\hline $\begin{array}{l}\mathbb{E} \\
\text { o }\end{array}$ & के & 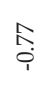 & $\begin{array}{l}\text { in } \\
\text { î }\end{array}$ & - & & & & & & & & & & & & & & & \\
\hline
\end{tabular}




\begin{tabular}{|c|c|c|c|c|c|c|c|c|c|c|c|c|c|c|c|c|c|c|c|}
\hline $\begin{array}{l}\mathbb{E} \\
\text { z }\end{array}$ & $\stackrel{m}{i}$ & ".; & $\stackrel{3}{9}$ & लै & - & & & & & & & & & & & & & & \\
\hline $\begin{array}{l}\text { 并 } \\
\text { 足 }\end{array}$ & 궁 & $\stackrel{0}{\stackrel{0}{i}}$ & $\stackrel{\text { 욤 }}{\circ}$ & $\stackrel{\infty}{-1}$ & ถิ & - & & & & & & & & & & & & & \\
\hline 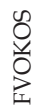 & $\stackrel{?}{:}$ & $\stackrel{\text { s. }}{\circ}$ & లై & $\stackrel{12}{0}$ & $\stackrel{8}{\circ}$ & कें & - & & & & & & & & & & & & \\
\hline 吾 & ֻٕ: & $\begin{array}{l}\text { त̂ } \\
\stackrel{1}{1}\end{array}$ & సे & लె & $\begin{array}{l}\stackrel{2}{\widehat{O}} \\
\mathrm{O}\end{array}$ & $\begin{array}{c}\infty \\
\substack{0 \\
0}\end{array}$ & $\stackrel{9}{O}$ & - & & & & & & & & & & & \\
\hline$\frac{n}{n}$ & $\stackrel{\text { ?: }}{\stackrel{0}{0}}$ & $\stackrel{0}{\circ}$ & กิ & $\vec{p}$ & $\stackrel{0}{\circ}$ & F゙ & "̈. & न.: & $r$ & & & & & & & & & & \\
\hline 梁 & 菅 & : & $\stackrel{\circ}{\circ}$ & o̊ & लె & สิ & Iี & s. & : & - & & & & & & & & & \\
\hline 8 & 莒 & Fे & స̃ & ț & $\stackrel{\infty}{-1}$ & oे & $\stackrel{\text { Oे }}{\circ}$ & नें & 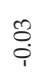 & oे & - & & & & & & & & \\
\hline 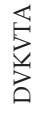 & F্ & ढे & ले & F্ & חָ & $\stackrel{m}{0}$ & సે & ָุ & oे & స్ & 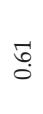 & - & & & & & & & \\
\hline 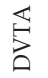 & ֻे & : & क़े & $\begin{array}{c}\text { ते } \\
\text { ?ें }\end{array}$ & $\stackrel{m}{0}$ & $\begin{array}{l}\text { o. } \\
\stackrel{i}{i}\end{array}$ & สู & $\begin{array}{l}\text { D্ } \\
\stackrel{i}{1}\end{array}$ & 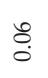 & ò. & $\stackrel{8}{\circ}$ & గึ? & $r$ & & & & & & \\
\hline $\begin{array}{l}\text { 岌 } \\
\end{array}$ & 苞 & $\begin{array}{l}\text { ț } \\
\text { i }\end{array}$ & $\stackrel{9}{6}$ & $\begin{array}{l}\text { ț } \\
\stackrel{9}{0}\end{array}$ & 웅 & $\begin{array}{l}\vec{S} \\
\stackrel{i}{0}\end{array}$ & $\stackrel{0}{\circ}$ & 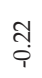 & ه: & ڤे. & 궁 & $\stackrel{\infty}{\stackrel{\infty}{9}}$ & $\stackrel{\infty}{\stackrel{\infty}{+}}$ & - & & & & & \\
\hline 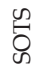 & $\overbrace{i}^{m}$ & $\begin{array}{c}\stackrel{L}{0} \\
\stackrel{0}{i}\end{array}$ & 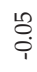 & तె & s. & 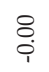 & 훙 & s. & $\widetilde{3}$ & ڤ্ডি & 苛 & $\underset{:}{\stackrel{H}{\prime}}$ & के & ๙ิ & \&. & - & & & \\
\hline के & $\stackrel{\widehat{c}}{0}$ & I? & $\stackrel{\circ}{\circ}$ & लि? & $\begin{array}{l}\text { ț } \\
\text { i }\end{array}$ & $\begin{array}{l}\text { tu } \\
\text { i }\end{array}$ & $\begin{array}{l}\text { 웅 } \\
\stackrel{2}{2}\end{array}$ & $\begin{array}{l}\text { tu } \\
\text { in }\end{array}$ & ָָ & ণิ & o̊ & İ & 占 & 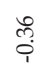 & s. & $\begin{array}{l}\text { tै } \\
\text { ôे }\end{array}$ & $r$ & & \\
\hline$\sum_{5}^{0}$ & $\stackrel{\text { i }}{\text { in }}$ & ֶֻ. & 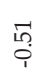 & $\stackrel{8}{\circ}$ & F: & 宫 & $\stackrel{\circ}{0}$ & : & $\stackrel{\circ}{\text { i }}$ & $\begin{array}{l}\text { 궁 } \\
\text { 10 }\end{array}$ & $\begin{array}{l}\text { ț } \\
\text { i }\end{array}$ & 苛 & $\vec{c}$ & 궁 & $\stackrel{8}{0}$ & ¿্: & 苞 & - & \\
\hline 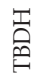 & 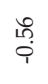 & $\vec{~}$ & Fे & ถึ? & $\stackrel{\mathscr{T}}{0}$ & F: & $\stackrel{\text { ֻొ }}{0}$ & สิ & ֶֻ. & $\begin{array}{l}\vec{b} \\
\stackrel{i}{i}\end{array}$ & $\stackrel{\text { : }}{0}$ & Iี & $\stackrel{0}{\circ}$ & $\stackrel{8}{0}$ & 궁 & $\begin{array}{l}\text { oे } \\
\text { iे }\end{array}$ & 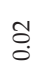 & oे & $r$ \\
\hline
\end{tabular}


Korelasyon tablosunu incelediğimizde aralarında yüksek düzeyde korelasyon ilişkisi olan değişkenler bulunduğunu görmekteyiz. Bunlar; kaldıraç oranı ile kısa vadeli borç oranı ve öz kaynak oranı; kısa vadeli borç oranı ile kaldıraç oranı ve öz kaynak oranı; öz kaynak oranı ile kaldıraç ve kısa vadeli borç oranı; aktif karlılık oranı ile net karlılık oranı; stok devir hızı ile stokların ortalama tüketim süresi arasında yüksek korelasyon ilişkisi olduğu tespit edilmiştir. Bu ilişkilerin yönü ve büyüklüğü tabloda görülmektedir. Bu değişkenler arasında yüksek korelasyon ilişkisi bulunması sebebiyle bu değişkenlerin hiçbirisi aynı modelde kullanılmamıştır. Yapılacak analizlerde aralarında yüksek korelasyon ilişkisi bulunan bağımlı değişkenlerden her birisi modellerde tek tek denenmiş ve en anlamlı sonuç veren değişkenlerin modellerde kullanılmasına karar verilmiştir.

Serilerde yatay kesit bağımlılı̆̆ı varsa bu duruma dikkate edilerek analiz yapılması gereklidir. Aksi takdirde analiz sonuçları sapmalı ve tutarsız hale gelebilmektedir. Bu doğrultuda serilerde yatay kesit bağımlılığı olup olmadığını test etmek amacıyla Breusch-Pagan (1980) LM testi, Pesaran (2004) CD ve CDlm testleri yapılmıştır. Burada yapılan testlerden hangisinin kullanılacağına karar vermek için veri setine bakılmaktadır. Eğer zaman boyutu yatay kesit boyutundan büyük ise Breusch-Pagan (1980) LM testi, yatay kesit ile zaman boyutu arasına çok büyük farkın olmadığ1 durumda Pesaran (2004) CDlm testi, yatay kesit zaman boyundan büyük ise bu durumda da Pesaran (2004) CD testinin sonuçları dikkate alınmaktadır (Topaloğlu, 2018:22). Bu çalışmada yatay kesit boyutu zaman boyutundan büyük olduğu için Pesaran (2004) CD testi sonuçları dikkate alınmıştır. Bu testlere ilişkin sonuçlar Tablo 5’ de yer almaktadır.

Tablo 5: Yatay Kesit Bağımlılığı Testleri

\begin{tabular}{|l|l|l|l|l|l|l|}
\hline \multicolumn{1}{|c|}{ Değgişkenler } & \multicolumn{2}{|c|}{ LM(Breusch, Pagan) } & \multicolumn{2}{c|}{$\begin{array}{c}\text { CDlm } \\
\text { (Pesaran ) }\end{array}$} & \multicolumn{2}{c|}{$\begin{array}{c}\text { CD } \\
\text { (Pesaran) }\end{array}$} \\
\hline & ist. & Olasılık & ist. & Olasılık & ist. & Olasılık \\
\hline TBTA & 155.164 & 0.000 & 8.501 & 0.000 & 6.120 & 0.000 \\
\hline KVBTA & 136.595 & 0.000 & 5.945 & 0.000 & -0.346 & $0.729^{*}$ \\
\hline UVBTA & 106.591 & 0.000 & 3.870 & 0.000 & 4.299 & 0.000 \\
\hline OKTA & 143.511 & 0.000 & 7.390 & 0.000 & 5.814 & 0.000 \\
\hline
\end{tabular}




\begin{tabular}{|l|l|l|l|l|l|l|}
\hline NKTA & 52.0806 & 0.586 & -1.327 & 0.184 & 2.714 & 0.006 \\
\hline FVOK & 55.4722 & 0.456 & -1.003 & 0.315 & 1.968 & 0.049 \\
\hline FVOKOS & 56.9427 & 0.402 & -0.863 & 0.387 & 0.761 & $0.446^{*}$ \\
\hline NKNS & 60.3412 & 0.288 & -0.539 & 0.589 & 1.521 & $0.128^{*}$ \\
\hline BKNS & 87.3319 & 0.003 & 2.033 & 0.042 & 2.083 & 0.037 \\
\hline FKNS & 66.7771 & 0.132 & 0.074 & 0.940 & 4.834 & 0.000 \\
\hline CO & 124.585 & 0.000 & 5.585 & 0.000 & 0.476 & $0.633^{*}$ \\
\hline DVTA & 72.1219 & 0.060 & 0.583 & 0.559 & 0.765 & $0.443^{*}$ \\
\hline DVKVTA & 110.036 & 0.000 & 4.198 & 0.000 & 1.342 & $0.179^{*}$ \\
\hline ALDH & 94.5221 & 0.000 & 2.719 & 0.006 & 0.960 & $0.336^{*}$ \\
\hline SDV & 60.1240 & 0.295 & -0.560 & 0.575 & -0.481 & $0.630^{*}$ \\
\hline SDH & 57.9714 & 0.366 & -0.765 & 0.444 & -0.892 & $0.372^{*}$ \\
\hline STOS & 56.9032 & 0.404 & -0.867 & 0.385 & -1.024 & $0.305^{*}$ \\
\hline UVBDH & 126.525 & 0.000 & 5.770 & 0.000 & 3.823 & 0.000 \\
\hline TBDH & 150.187 & 0.000 & 8.026 & 0.000 & 4.356 & 0.000 \\
\hline
\end{tabular}

*\% 5 düzeyinde anlamlı

Yatay kesit bağımlılı̆̆ı testi sonuçlarına göre eğer olasılık değeri 0,05'den küçük ise yatay kesit bağımlılığı var demektir. Bu durumda serilerin durağanlık sınamasında ikinci nesil birim kök testleri kullanılmalıdır. Eğer olasılık değeri 0.05 'den büyükse yatay kesit bağımlılığı yok demektir. Bu durumda ise birinci nesil birim kök testleri kullanılabilmektedir. Yatay kesit bağımlılık testi sonuçlarının yer aldığı tabloyu incelediğimizde TBTA, UVBTA, OKTA, NKTA, FVOK, BKNS, FKNS, UVBDH ve TBDH yatay kesit bağımlılı̆̆ı olduğu tespit edilmiştir. Diğer değişkenler arasında ise yatay kesit bağımlılığı bulunmadığı görülmüştür. Yatay kesit bağımlılığı olan değişkenler yatay kesit bağımlılığını dikkate alan ikinci nesil birim kök testi olan Hadri-Kuruzomi birim kök testi ile durağanlık sınamasına tabi tutulmuştur. Diğer değişkenler ise birinci nesil birim kök testlerinden LLC testi kullanılarak durağanlık sınaması yapılmıştır. Birim kök testlerine ilişkin sonuçlar ise Tablo 6' da yer almaktadır. 
Tablo 6: Birim Kök Testi Sonuçları

\begin{tabular}{|c|c|c|c|c|}
\hline \multirow[t]{2}{*}{ Değişkenler } & \multicolumn{2}{|c|}{ LLC } & \multicolumn{2}{|c|}{ Hadri-Kuruzomi } \\
\hline & İstatistik & Olasilik & İstatistik & Olasılık \\
\hline TBTA & & & 1.8159 & 0.9653 \\
\hline KVBTA & -3.7258 & $0.0001^{*}$ & & \\
\hline UVBTA & & & 2.0566 & 0.9801 \\
\hline OKTA & & & 1.7528 & 0.9602 \\
\hline NKTA & & & -1.2700 & 0.1020 \\
\hline FVOK & & & 0.6317 & 0.7362 \\
\hline FVOKOS & -2.0316 & $0.0211^{*}$ & & \\
\hline NKNS & -2.3321 & $0.0098^{*}$ & & \\
\hline BKNS & & & 1.2351 & 0.8916 \\
\hline FKNS & & & 1.6916 & 0.9546 \\
\hline $\mathrm{CO}$ & -1.5994 & $0.0540^{*}$ & & \\
\hline DVTA & -3.7957 & $0.0001^{*}$ & & \\
\hline DVKVTA & -7.4911 & $0.0000^{*}$ & & \\
\hline SDV & -1.6917 & $0.0453^{*}$ & & \\
\hline ALDH & -4.4264 & $0.0000^{*}$ & & \\
\hline $\mathrm{SDH}$ & -2.6319 & $0.0042^{*}$ & & \\
\hline SOTS & -2.7847 & 0.0027 & & \\
\hline UVBDH & & & -0.3026 & 0.3811 \\
\hline TBDH & & & -0.6560 & 0.2559 \\
\hline
\end{tabular}

* \% 5 düzeyinde anlamlı

Yapılan birinci nesil birim kök testlerine ilişkin sonuçları incelediğimizde bütün değişkenlerin düzey değerinde durağan olduğu belirlenmiştir. Hadri kuruzomi testinde ters hipotez geçerlidir. Yani olasılık değerleri $0.05^{\prime}$ den büyük ise seriler durağandır. Bu test ile ilgili sonuçları incelediğimizde ise ilgili serilerin sabit terimli ve trenli hallerinin durağan olduğu tespit edilmiştir.

$\mathrm{Bu}$ aşamadan sonra ise panel veri analizinde hangi yöntemin kullanılacağına karar vermek amacıyla bazı istatistiki testler yapılmıştır. Bunlara ilişkin sonuçlar ise sırasıyla aşağıdaki tablolarda yer almaktadır. İlk olarak verilerde birim zaman farklılığı olup olmadığını tespit etmek amacıyla F testi yapılmıştır. Bu test havuzlanmış en küçük kareler yöntemi ile sabit etkiler modeli arasında tercih yapmak amacıyla yapılmaktadır. Bu teste ilişkin hipotezler ise şunlardır;

$\mathrm{H}_{0}$ : Birey ve zaman etkisi yoktur. $\mathrm{H}_{\mathrm{a}}$ : Birey ve zaman etkisi vardır. 
Tablo 7: F testi Sonuçları

\begin{tabular}{|l|c|c|c|c|}
\hline \multicolumn{1}{|c|}{ F Testi } & Model 1 & Model 2 & Model 3 & Model 4 \\
\hline İstatistik & 13.8173 & 10.4200 & 5.3227 & 3.9338 \\
\hline Olasılik & $0.0000^{*}$ & $0.0000^{*}$ & $0.0000^{*}$ & $0.0004^{*}$ \\
\hline
\end{tabular}

*\% 5 Düzeyinde anlamlı

Bütün modellere ilişkin F testi sonuçlarının yer aldığı tabloyu incelediğimizde modellerin hepsinde $\mathrm{H}_{0}$ hipotezi reddedilmiş ve alternatif hipotez kabul edilmiştir. Yani F testi sonuçlarına göre modellerde sabit etkiler yönteminin kullanımı uygun bulunmuştur.

İkinci olarak da Breusch-Pagan LM Testi ve Honda yapılmıştır. Bu testlerde birim etkiler varyansı sıfır ise oluşacak rassal etkinin havuzlanmış model ile çözülebileceği kabul edilmektedir. Bu testin hipotezleri ise aşağıdaki gibidir; $\mathrm{H}_{0}$ : Havuzlanmış en küçük kareler yönteminin kullanımı uygundur. $\mathrm{H}_{\mathrm{a}}$ : Tesadüfi etkiler yönteminin kullanımı uygundur

Tablo 8: Breusch-Pagan LM Testi ve Honda Testi Sonuçları

\begin{tabular}{|c|c|c|c|c|}
\hline \multirow{2}{*}{$\begin{array}{c}\text { Model } \\
\text { no }\end{array}$} & \multicolumn{2}{|c|}{ Breusch-Pagan LM } & \multicolumn{2}{c|}{ Honda } \\
\cline { 2 - 5 } & Model & Olas1lik & Model & Olasilik \\
\hline 1 & 91.9180 & $(0.0000)$ & 5.8185 & $(0.0000)^{*}$ \\
\hline 2 & 62.4643 & $(0.0000)$ & 4.1488 & $(0.0000)^{*}$ \\
\hline 3 & 13.2264 & $(0.0003)^{*}$ & 2.2803 & $(0.0113)$ \\
\hline 4 & 1.09599 & $(0.2951)$ & 0.9126 & $(0.1807)$ \\
\hline
\end{tabular}

*\% 5 Düzeyinde anlamlı

Yapılan testler sonucunda dört numaralı model haricinde diğer modellerde sıfır hipotezi reddedilmiş ve alternatif hipotez kabul edilmiştir.

$\mathrm{Bu}$ testten sonra ise tesadüfi etkiler ve sabit etkiler yöntemlerinden hangilerinin modellerde kullanılacağına karar vermek amacıyla Hausman Testi yapılmıştır. Bu testin hipotezleri ise şunlardır;

$\mathrm{H}_{0}$ : Tesadüfi Etkiler Modeli Uygundur. $\mathrm{H}_{\mathrm{a} \text { : }}$ Sabit Etkiler Modeli Uygundur. 
Tablo 9: Hausman Testi Sonuçları

\begin{tabular}{|l|c|c|c|c|}
\hline \multicolumn{1}{|c|}{ Hausman } & Model 1 & Model 2 & Model 3 & Model4 \\
\hline Ki-Kare & 2.0261 & 4.5007 & 53.5178 & 25.3705 \\
\hline Olasılık & 0.9584 & 0.6092 & $0.0000^{*}$ & $0.0047^{*}$ \\
\hline
\end{tabular}

* \% 5 Düzeyinde anlaml

* işareti olan bütün modellerde H0 hipotezi reddedilmiş alternatif hipotez kabul edilmiştir. Yani 1 ve 2 numaralı model haricinde bütün modellerde sabit etkiler yönteminin kullanımı uygun bulunmuştur.

Bunun dişında modellerde Otokorelasyon ve değişen varyans sorunu olup olmadığını tespit etmek amacıyla Pesaran CD ve Wald Testi yapılmıştır. İlgili testlere ilişkin sonuçlar Tablo 10' da yer almaktadır.

Tablo 10: Pearson CD ve Wald Testi Sonuçları

\begin{tabular}{|c|c|c|c|c|}
\hline & \multicolumn{2}{|c|}{ Pearson Testi } & \multicolumn{2}{c|}{ Wald Testi } \\
\hline & İstatistik & Olas1lı & Chi-square & Olasılık \\
\hline Model 1 & -1.9391 & $0.0525^{*}$ & 0.5097 & $0.4753^{*}$ \\
\hline Model 2 & -1.0794 & $0.2804^{*}$ & 8.1209 & 0.0044 \\
\hline Model 3 & 0.7607 & $0.4468^{*}$ & 8.3924 & 0.0038 \\
\hline Model 4 & -1.8978 & $0.0577^{*}$ & 3.0614 & $0.0802^{*}$ \\
\hline
\end{tabular}

* \% 5 düzeyinde anlamlı

İlgili test sonuçlarını incelediğimizde modelde Otokorelasyon sorunu olup olmadığını tespit etmek amacıyla Pearson CD testi yapılmıştır. Bu testte olasılık değeri 0.05 'ten büyükse Otokorelasyon yoktur demektir. Tabloyu incelediğimizde bütün modellerde Otokorelasyon sorunu olmadiğı görülmüştür. Modellerde değişen varyans sorunu olup olmadığını tespit etmek amacıyla Wald testi yapılmıştır. Bu testte de olasılık değeri 0.05 'den küçükse değişen varyans sorunu var demektir. Bu durumda modellerde düzeltme yapılmalıdır. Tabloyu incelediğimizde model 2 ve model3'de değişen varyans sorunu olduğu tespit edilmiştir. Bu sorun modellerde White cross-section düzeltmesi yapılarak giderilmiştir. 


\subsection{Analiz Sonuçları}

Çalışmada kullanılan modellere ilişkin analiz sonuçları ve bu sonuçlara ilişkin yorumlar aşağıdaki tablolar da gösterilmiştir.

Tablo 11: Model 1 Analiz Sonuçları

\begin{tabular}{|l|c|c|c|c|}
\hline \multicolumn{1}{|c|}{ Değişkenler } & Katsayılar & Std. Hata & t-istatistik & Olasıllı \\
\hline Bağımlı değişken TBTA & \multicolumn{4}{|c|}{ Yöntem: Sabit Etkiler } \\
\hline NKTA & 0.0813 & 0.2955 & 0.2752 & 0.7840 \\
\hline FVOK & -0.7263 & 0.2290 & -3.1713 & $0.0023^{* *}$ \\
\hline BKNS & 0.5846 & 0.1567 & 3.7292 & $0.0004^{* * *}$ \\
\hline FKNS & 0.1716 & 0.0962 & 1.7829 & $0.0789^{*}$ \\
\hline DVKVTA & -0.3132 & 0.1356 & -2.3096 & $0.0239^{* *}$ \\
\hline LOGSOTS & -0.0239 & 0.0425 & -2.4097 & $0.0186^{\text {** }}$ \\
\hline TBDH & -0.1021 & 0.0240 & -4.2552 & $0.0001^{\text {*** }}$ \\
\hline C & 1.0506 & 0.1932 & 5.4368 & $0.0000^{* * *}$ \\
\hline$R^{2}$ & 0.8637 & Düzeltilmiş $R^{2}$ & \multicolumn{2}{c|}{0.8306} \\
\hline F-istatistik & 26.1075 & Olasıllik & \multicolumn{2}{c|}{0.0000} \\
\hline
\end{tabular}

* \%10, ** \%5 ve *** \%1 anlam düzeyini göstermektedir

Model1'e ilişkin analiz sonuçlarına baktığımızda; model1'de kaldıraç oranı bağımlı değişken olarak kullanılırken aktif karlılık oranı, faiz vergi öncesi kar oranı, brüt kar oranı, faaliyet karı oranı, çalışma sermayesi oranı, stokların ortalama tüketim süresi, işletme sermayesi devir hizı ve toplam borç devir hızı ise bağımsız değişken olarak kullanılmıştır. Modelin olasılık değeri 0.05 ' de küçüktür ve açıklama gücü yani R2 değeri 0.86 olarak tespit edilmiştir. Bunun anlamı modelimizin anlamlı ve açıklama gücünün ise yüksek olduğunu göstermektedir. Yani modelin açıllama gücü \%86'dir. Bağımsız değişkenler bağımlı değişkeni \%86 oranında açıklamaktadır. Modelde kullanılan değişkenler ile kaldıraç oranı arasındaki ilişkilere baktığımızda kaldıraç oranı ile faiz ve vergi öncesi kar oranı, brüt kar oranı, çalışma sermayesi oranı, toplam borç devir hızı ve stokların ortalama tüketim süresi arasında anlamlı bir ilişki olduğu tespit edilmiştir. Buna karşın aktif karlılık oranı, faaliyet karı oranı ile kaldıraç oranı arasında ise anlamlı bir ilişki bulunmadığı görülmüştür. Buna ek olarak kaldıraç oranı ile faiz vergi öncesi kar oranı, çalışma sermayesi oranı, stokların ortalama tüketim süresi arasındaki ilişkinin yönü negatif; brüt kar oranı ile ise pozitif olarak belirlenmiştir. 
Yani faiz vergi öncesi kar oranı, çalışma sermayesi oranı ve stokların ortalama tüketim süresi artıkça kaldıraç oranı azalmakta brüt kar oranı arttıkça ise artmaktadır.

Tablo 12: Model 2 Analiz Sonuçları

\begin{tabular}{|l|c|c|c|c|}
\hline \multicolumn{1}{|c|}{ Değişkenler } & Katsayılar & Std. Hata & t-istatistik & Olasılık \\
\hline $\begin{array}{l}\text { Bağımlı değişken } \\
\text { KVBTA }\end{array}$ & \multicolumn{4}{|c|}{ Yöntem: White cross-section } \\
\hline NKNS & -0.1612 & 0.0783 & -2.0593 & $0.0431^{* *}$ \\
\hline CO & -0.0358 & 0.0037 & -9.6335 & $0.0000^{* * *}$ \\
\hline DVTA & 0.3395 & 0.0354 & 9.5762 & $0.0000^{* * *}$ \\
\hline SDH & -0.0023 & 0.0069 & -0.3360 & 0.7378 \\
\hline ALDH & -0.0014 & 0.0046 & -0.3129 & 0.7552 \\
\hline UVBDH & 0.0011 & 0.0003 & 3.4826 & $0.0009^{* * *}$ \\
\hline C & 0.2809 & 0.0471 & 5.9569 & $0.0000^{* * *}$ \\
\hline$R^{2}$ & 0.9044 & Düzeltilmiş $R^{2}$ & 0.882946 \\
\hline F-istatistik & 42.0153 & Olasilik & \multicolumn{2}{c|}{0.0000} \\
\hline
\end{tabular}

*\%10, ** \%5 ve *** \%1 anlam düzeyini göstermektedir

Kısa vadeli borç oranının bağımlı değişken net kar oranı, cari oran, dönen varlık oranı, stok devir hızı, alacak devir hızı ve uzun vadeli borç devir hızının bağımsız değişken olarak kullanıldığı model2'ye ilişkin sonuçların yer aldığı tabloyu incelediğimizde model genel olarak anlamlıdır ve açıklama gücü \%90'dır. Kısa vadeli borç oranı ile net kar oranı, cari oran, dönen varlıklar/ toplam aktif oranı ve uzun vadeli borç devir hızı arasında anlamlı bir ilişki tespit edilmiştir. Buna karşın stok devir hızı ve alacak devir hızı ile kısa vadeli oranı arasında ise anlamlı bir ilişki bulunamamıştır. Ayrıca kısa vadeli borç oranı ile net kar oranı ve cari oran arasındaki ilişkinin yönü negatif; dönen varlık oranı ve uzun vadeli borç devir hızı ile ise pozitif olarak belirlenmiştir. Daha net bir biçimde ifade etmek gerekirse net kar oranı ve cari oran artıkça kısa vadeli borç oranı azaltmaktadır. Buna karşın uzun vadeli borç devir hızı arttıkça kısa vadeli borç oranı artmaktadır uzun vadeli borç devir hızı oranı azaldıkça ise kısa vadeli borç oranı azalmaktadır 
Tablo 13: Model 3 Analiz Sonuçları

\begin{tabular}{|l|c|c|c|c|}
\hline \multicolumn{1}{|c|}{ Değişkenler } & Katsayılar & Std. Hata & t-istatistik & Olasıllk \\
\hline Bağımlı değişken UVBTA & \multicolumn{4}{|c|}{ Yöntem: White cross-section } \\
\hline FVOK & -0.4668 & 0.2591 & -1.8017 & 0.0758 \\
\hline UVBDH & -0.0019 & 0.0006 & -2.9171 & $0.0047^{* * *}$ \\
\hline TBDH & -0.0635 & 0.0081 & -7.7535 & $0.0000^{* * *}$ \\
\hline NKNS & 0.0280 & 0.0560 & 0.4993 & 0.6191 \\
\hline BKNS & 0.3965 & 0.1818 & 2.1809 & $0.0325^{\text {** }}$ \\
\hline C & 0.1693 & 0.0288 & 5.8773 & $0.0000^{* * *}$ \\
\hline$R^{2}$ & 0.7199 & Düzeltilmiş $R^{2}$ & \multicolumn{2}{c|}{0.6616} \\
\hline F-istatistik & 12.3413 & Olasılık & \multicolumn{2}{c|}{0.0000} \\
\hline
\end{tabular}

* \%10, ** \%5 ve *** \%1 anlam düzeyini göstermektedir

Model3'e ilişkin analiz sonuçlarının yer aldığı Tablo 3'de ise uzun vadeli borç oranı bağımlı değişken olarak kullanılırken faiz vergi öncesi kar oranı, uzun vadeli borç devir hızı, net kar oranı, toplam borç devir hızı, brüt kar oranı ise bağımsız değişken olarak kullanılmıştır. Modelde bağımsız değişkenlerin bağımlı değişkeni açıklama gücü \%71 olarak belirlenmiştir. Modelin olasılık değeri 0.05 'den küçük olduğu için model genel olarak anlamlı ve açıklama gücü oldukça yüksektir. Modelde bağımlı değişken ile bağımsız değişken arasındaki ilişkilere baktığımızda uzun vadeli borç oranı ile uzun vadeli borç devir hızı, toplam borç devir hızı ve brüt kar oranı arasında anlamlı bir ilişki tespit edilirken net kar oranı, faiz ve vergi öncesi kar oranı ve uzun vadeli borç oranı arasında anlamlı bir ilişki tespit edilememiştir. Uzun vadeli borç devir hızı, toplam borç devir hızı artıkça uzun vadeli borç oranının azaldığı yani bu oranlarla uzun vadeli borç oranı arasında negatif yönlü bir ilişki olduğu belirlenmiştir. Buna ek olarak brüt kar oranı ile uzun vadeli borç oranı arasında ise pozitif yönlü bir ilişki olduğu görülmüştür. 
Tablo 14: Model 4 Analiz Sonuçları

\begin{tabular}{|l|c|c|c|c|}
\hline \multicolumn{1}{|c|}{ Değişkenler } & Katsayılar & \multicolumn{1}{c|}{ Std. Hata } & \multicolumn{1}{c|}{ t-istatistik } & Olasılık \\
\hline Bağımlı değişken OKTA & \multicolumn{4}{|c|}{ Yöntem: Sabit Etkiler } \\
\hline NKTA & -0.4892 & 0.27962 & -1.7496 & $0.0853^{*}$ \\
\hline FVOK & 0.7033 & 0.1979 & 3.5532 & $0.0007^{* * *}$ \\
\hline FVOKOS & 0.0271 & 0.0210 & 1.2886 & 0.2025 \\
\hline BKNS & -0.4948 & 0.1357 & -3.6460 & $0.0006^{* * *}$ \\
\hline FKNS & -0.1312 & 0.0906 & -1.4482 & 0.1528 \\
\hline CO & -0.0028 & 0.0098 & -0.2953 & 0.7688 \\
\hline DVTA & -0.9750 & 0.1707 & -5.7091 & $0.0000^{* * *}$ \\
\hline DVKVTA & 1.1060 & 0.1725 & 6.4082 & $0.0000^{* * *}$ \\
\hline SDV & 0.0382 & 0.1864 & 0.2051 & 0.8381 \\
\hline UVBDH & 0.0012 & 0.0005 & 2.1706 & $0.0339^{* *}$ \\
\hline C & 0.8934 & 0.1265 & 7.0581 & 0.0000 \\
\hline$R^{2}$ & 0.9189 & Düzeltilmiş $\mathrm{R}^{2}$ & \multicolumn{2}{c|}{0.8824} \\
\hline F-istatistik & 25.19636 & Olasıllk & \multicolumn{2}{c|}{0.0000} \\
\hline
\end{tabular}

*\%10, ** \%5 ve *** \%1 anlam düzeyini göstermektedir

Öz kaynak oranının bağımlı değişken olarak kullanıldı̆̆ı bu modelde aktif karlılık oranı, faiz vergi öncesi kar oranı, faiz vergi öncesi/ öz sermaye oranı, brüt kar oranı, faaliyet karı oranı, cari oran, dönen varlık oranı, çalışma sermayesi oranı, stok devir hızı ve uzun vadeli borç devir hızı ise bağımsız değişken olarak kullanılmıştır. Modelin olasılık değeri $0.05^{\prime}$ den küçük olduğu için model anlamlıdır. Modelde bağımsız değişkenlerin bağımlı değişkeni açıklama gücü \%91 olarak belirlenmiştir. Bağımsız değişkenlerin bağımlı değişkeni açılama gücü oldukça yüksektir. Bağımlı değişken ile bağımsız değişken arasındaki ilişkilere baktı̆̆ımızda; öz kaynak oranı ile aktif karlılık oranı, brüt kar oranı dönen varlık oranı arasında negatif; öz kaynak oranı ile faiz vergi öncesi kar oranı, çalışma sermayesi oranı ve uzun vadeli borç devir hızı arasında ise pozitif yönlü ve anlamlı bir ilişki bulunduğu tespit edilmiştir.

\section{Sonuç ve Öneriler}

Sermaye yapısı kararları sermaye maliyeti üzerinde doğrudan etkili olduğu için finans yöneticileri tarafından üzerinde dikkatle durulması gereken konular içerisinde yer almaktadır. Konun önemi sebebiyle sermaye yapısı kararları finans literatüründe sıkça araştırılan konular arasında yer almaktadır. Literatürde Türkiye' de yapılan çalışmalarda 
genellikle sermaye yapısı kararları sermaye yapısı teorileri ile ilişkilendirilmiş ve sermaye yapısı kararlarının karlılık üzerine etkisi araştırılmıştır. Buna karşın sermaye yapısı kararları üzerine etkili olan faktörlerin tespitine yönelik sınırlı sayıda çalışma bulunduğu görülmüştür.

Bu çalışmada BİST Tekstil ve Deri Endeksinde yer alan firmaların sermaye yapısı kararları üzerinde etkili olan faktörlerin tespit edilmesi amaçlanmıştır. Çalışmada ilk olarak firmaların bilanço ve gelir tablosu verileri kullanılarak finansal oranları hesaplanmıştır. Daha sonra ise bu oranlar kullanılarak dengeli panel veri analizi yapılmıştır. Analizde sermaye yapısı kararları ile ilgili dört farklı bağımsız değişken ve bu doğrultuda ise dört farklı model kullanılmıştır.

Yapılan analiz sonuçlarına ilişkin genel bir değerlendirme yapacak olursak model 2 haricinde bütün modellerde faiz vergi öncesi kar oranı ile sermaye yapısı değişkenleri arasında anlamlı bir ilişki olduğu tespit edilmiş bu ilişkinin yönü öz kaynak oranının bağımlı değişken olarak kullanıldığ 1 modelde pozitif diğerlerinde ise negatif olarak belirlenmiştir. Model2 dışında diğer modellerde ortak olarak kullanılan bir diğer bağımsız değişken ise brüt kar oranıdır. Brüt kar oranı ile sermaye yapısı değişkenleri arasında anlamlı bir ilişki olduğu modellere ilişkin sonuçların yer aldığı tablolarda görülmektedir. Brüt kar oranı ile kaldıraç ve uzun vadeli borç oranı arasındaki ilişkinin yönü pozitif olarak belirlenirken öz kaynak oranı ile brüt kar oranı arasındaki ilişkinin yönünün ise negatif olduğu tespit edilmiştir. Çalışma sermayesi oranı ve toplam borç devir hızı oranı ile uzun vadeli borç oranı ve kaldıraç oranı arasında da anlamlı bir ilişki olduğu belirlenmiştir. Uzun vadeli borç devir hızı ile kısa vadeli borç oranı, uzun vadeli borç oranı ve öz kaynak oranı arasında da anlamlı bir ilişki olduğu tespit edilmiştir. Bu ilişkinin yönü öz kaynak oranı ve kısa vadeli borç oranı ile pozitif; uzun vadeli borç oranı ile negatif olarak belirlenmiştir. Sonuçları finans teorileri ile ilişkilendirecek olursak karlılık ve likidite değişkenleri ile sermaye yapısı oranları arasında negatif ilişki bulunması finansal hiyerarşisi teorisinin geçerli olduğunu göstermektedir. Bu bakımdan bütün modellerde finansal hiyerarşi teorisinin geçerli olduğu söyleyebiliriz. Finansal hiyerarşi teorisinde firmaların sermaye yapısı oluştururken ilk olarak içsel kaynaklardan faydalandığ i içsel kaynakların yeterli olmadığ 1 koşullarda borçlanma araçlarını tercih ettiği ve en son kademede ise firmaların hisse senedi ihracına yöneldiği ifade edilmektedir. 
Bu çalışmada sermaye yapısı üzerinde etkili olan finansal oranlar çok yönlü olarak, endeks bazında incelemiş ve daha önce literatürde kullanılmayan birçok değişken analizlerde kullanılmış bu doğrultuda anlamlı sonuçlar elde edilmiştir. Bu bakımdan çalışmanın literatüre katkı sağlayacağı düşünülmektedir. Bundan sonra konu ile ilgili olarak yapılacak çalışmalarda farklı endeksler ve makroekonomik değişkenler kullanılarak yeni çalışmalar yapılabilir.

\section{Kaynakça}

Akgül, E. F., ve Sigalı, S. (2018). “Determinants of Capital Structure: An Application on BIST Transportation Index". Muhasebe ve Finansman Dergisi, 77, s. 193-215.

Albayrak, A.S., ve Akbulut, R. (2008). “Sermaye Yapısını Belirleyen Faktörler: İMKB Sanayi Ve Hizmet Sektörlerinde İşlem Gören İşletmeler Üzerine Bir İnceleme". Dumlupınar Üniversitesi Sosyal Bilimler Dergisi, 22, s. 1-22.

Alsu, E. (2017). “Sermaye Yapısının Kârlılık Üzerindeki Etkisi BIST 100 Üzerine Panel Veri Analizi". Gaziantep University Journal of Social Sciences, 16 (2), s. 303-312.

Ayaydın, H., Pala, F., ve Barut, A. (2017). “Borsa İstanbul’da İşlem Gören Yüksek Teknoloji Şirketlerinin Sermaye Yapılarının Belirleyicileri Üzerine Bir Analiz". Ekonomi Bilimleri Dergisi, 9(2), s. 43-58.

Belas, J., Gavurova, B., and Toth, P. (2018,)." Impact Of Selected Characterstic Of SMES On The Capital Structure". Journal of Business Economics and Management, 19(4), s. 592-608.

Bozkurt, İ. (2014). “Dengeleme Teorisi'nin Geçerliliğinin Panel Veri Analizi ile Test Edilmesi: BİST'de Ampirik Bir Uygulama". Yönetim ve Ekonomi, 21(2), s. 164-178.

Brigham, E., and Ehrhardt, M. (2005). Financial Management (11 b.). Edition Thomson South Western.

Brigham, E., and Houston, J. (1999). Fundamentals Of Financial Management (9 b.). Edition Harcourt.

Burucu, H., ve Öndeş, T. (2016). “Türk İmalat Sanayi Firmalarının Sermaye Yapısını Etkileyen Faktörlerin Analizi”. Çankırı Karatekin Üniversitesi İktisadi ve İdari Bilimler Fakültesi Dergisi, 6(1), s. 201-225. 
Chen, S.-Y., and Chen, L.-J. (2011). "Capital structure determinants: An empirical study in Taiwan". African Journal of Business Management, 5(27), s. 10974-10983.

Coşkun, N., ve Topaloğlu, E. E. (2016). Makroekonomik Faktörlerin Finansal Performansa Etkisi: Borsa İstanbul Firmaları Üzerine Ekonometrik Bir Uygulama. ICOMEP 2016 International Congress of Management Economy and Policy Proceedings Book, 1-18.

Çoşkun, A., Güngör, B., ve Çodur, M. Y. (2015). “Yapay Sinir Ağ1 Yöntemi ile Sermaye Yapısını Etkileyen Faktörlerin". Atatürk Üniversitesi Sosyal Bilimler Enstitüsü Dergisi, 19(2), s. 333-350.

Demirhan, D. (2009). “Sermaye Yapısını Etkileyen Firmaya Özgü Faktörlerin Analizi: IMKB Hizmet Firmaları Üzerine Bir Uygulama". Ege Akademik Bakış, 9(2), s. 677-697.

Doğan, M. (2013). “Sigorta Firmalarının Sermaye Yapısı İle Karlılık Arasındaki İlişki: Türk Sermaye Piyasası Üzerine Bir İnceleme". Muhasebe ve Finansman Dergisi, 57, s. 121-136.

Erol, A. F., Aytekin, S., ve Abdioğlu, N. (2016). “İşletmelerin Sermaye Yapılarının Belirlenmesinde Finansal Hiyerarşi Teorisinin Kullanımı ve BIST'te Bir Uygulama". KSÜ Sosyal Bilimler Dergisi, 13(1), s. 114-128.

Firatoğlu, B. (2005). Şirketlerin Sermaye Yapısın Etkileyen Faktörler ve Kriz Dönemlerinde Şirket Davranışlarında Meydana Gelen Değişimler, Ankara: Sermaye Piyasası Kurulu Araştırma Dairesi.

Graham C., H. P. (2004). "Determinants of the Capital”. Journal of Business Finance \& Accounting, 711-728.

Güler, S. (2010). “İstanbul Menkul Kıymatler Borsasına Kayıtlı Küçük ve Orta Büyüklükteki İşletmelerin Sermaye Yapıları Üzerine Bir Uygulama". Süleyman Demirel Üniversitesi İktisadi ve İdari Bilimler Fakültesi Dergisi, 15(3), s. 353-371.

Jami, M., \& Koloukhi, A. S. (2018). "Determinants of Capital Structure and Performance in Listed Companies of Tehran Stock Exchange". International Journal of Management, Accounting and Economics, 5(11), s. 849-860.

Kamuyu Aydınlatma Platformu. (2019). Ocak 2019 tarihinde Kamuyu Aydınlatma Platformu: https://www.kap.org.tr/tr/ adresinden alındı 
Karadeniz, E., Kaplan, F., ve Günay, F. (2016). “Sermaye Yapısı Kararlarının Kârlılığa Etkisi: Borsa İstanbul Turizm Şirketlerinde Bir Araştırma". Seyahat ve Otel İşletmeciliği Dergisi,13(3), s. 38-55.

Linda H., C. R. (1998). The Determinants of Capital Structure:Evidence from Dutch Panel Data. The European Economic Association Annual Congress, (s. 1-33). Berlin.

Panda, S. (2015). Factors Affecting Capital Structure of Indian Venture Capital Backed Growth Firms (6 b.). İndia: Entrepreneurial Ecosystem Springer.

Saona, P., Martín, P. S., and Jara, M. (2018). “Group Affiliation and Ownership Concentration as Determinants of Capital Structure Decisions:Contextualizing the Facts for an Emerging Economy". Emerging Markets Finance \& Trade, 54, s. 3312-3329.

Tatoğlu, F. Y. (2012). Panel veri ekonometrisi: Stata uygulamal. Beta Basım Yayin.

Topaloğlu, E. E. (2018). “Bankalarda Finansal Kırılganlığı Etkileyen Faktörlerin Panel Veri Analizi ile Belirlenmesi". Eskişehir Osmangazi Üniversitesi İİB Dergisi, 13(1), s. 15-38.

Uysal, B. (2010). Sermaye Yapısını Belirleyen Faktörler: Sektörel Bir İnceleme. Ankara: Anakara üniversitesi Sosyal Bilimler Enstitüsü/ Yayınlanmış Yüksek Lisans Tezi.

Yousaf, S., and Iftikhar, K. (2018). "Firm-Specific Determinants of Capital Structure: Implication of Pecking Order Theory in Automotive Industry of Pakistan". Abasyn Journal of Social Sciences, s. 1-9. 